\title{
Economic feasibility and management considerations in range revegetation
}

\author{
JOHN P. WORKMAN AND JOHN A. TANAKA
}

\begin{abstract}
Although range researchers and managers involved in range revegetation often have little economics training, economic analysis is usually a crucial step in range revegetation decisions. This synthesis paper is intended to provide a useful background in economic analysis for teachers, students, and natural resource professionals who deal with range revegetation. First, 3 economic standards by which all revegetation projects must be judged are described and interpreted: (1) economic feasibility, (2) economic efficiency, and/or (3) cost effectiveness. Next, the information required for economic analysis and the analytical procedures used to evaluate range revegetation projects are described. A detailed reseeding example is then used to describe the following information requirements: project costs, benefits, value of benefits, interest rate (including real vs. nominal rates), risk, project life (including life extension and grazing deferment), and range site selected for revegetation. Last, procedures for determining optimal vegetation conversion and use are reviewed, emphasizing the vegetation response function as the key to balancing the 3 determinants of long-term net returns: initial vegetation conversion, grazing intensity, and project life.
\end{abstract}

Key Words: economic efficiency, economic analysis, vegetation conversion, optimal use

Although range researchers, managers, and others involved in range revegetation often have little formal economics training, economic analysis is usually a crucial step in range revegetation decisions. We offer the following synthesis paper as useful background in economic analysis for teachers, students, and natural resource professionals who deal with the important topic of range revegetation.

\section{Economic Analysis of Revegetation Projects - The General Case}

Economic analysis of revegetation projects involves judging such projects by 1 or more of the following economic standards: (1) economic feasibility, (2) economic efficiency, and/or (3) cost effectiveness.

\section{Economic Feasibility -Will the Project "Pay"?}

Mathematically, economic feasibility could be called the necessary condition for maximum net returns (Workman 1984). A project is said to be economically feasible if it yields a positive net return (i.e., discounted returns exceed discounted costs). An economically feasible project has a net present value (NPV) $\geq 0$, a benefit / cost (B/C) ratio $\geq 1$, and an internal rate of return (IRR) $\geq$ the appropriate discount rate (Workman 1986). A positive NPV indicates feasibility because the project yields a positive net return (a profit) after paying all costs, including interest on borrowed capital. A B/C ratio greater than 1.0 indicates feasibility because discounted benefits exceed discounted costs (i.e., more than a dollar is returned for each dollar invested). An IRR greater than the

Authors are professor, Range Science Department, Utah State University, Logan 84322-5230; and assistant professor, Agricultural and Resource Economics Department, Oregon State University, Corvallis 97331.

Supported by the Utah Agricultural Experiment Station, Utah State University, Logan 84322-4845. Approved as journal paper 3880.

Manuscript accepted 6 May 1991. interest rate on borrowed money indicates feasibility because the discount rate that forces future net returns to equal the present investment exceeds the borrowing rate.

\section{Economic Efficiency - the "Biggest Bang for the Buck"}

Mathematically, economic efficiency could be called the sufficient condition for achieving maximum net returns (Workman 1984). A project is considered to be economically efficient if it represents the most productive use of available capital and other required inputs. Thus an economically efficient project yields a higher net return than any other potential use of limited capital (i.e., an efficient project promises the "biggest bang for the buck"). Not only is the NPV for an efficient project positive, it is the maximum NPV possible from available capital.'

\section{Cost Effectiveness-a "Specified Bang for the Smallest Buck"}

No range manager has sufficient budget to implement all biologically sound and economically feasible improvements on rangeland under his/her control, and a choice must be made from among those available. These decisions are further complicated by what have been termed "critical projects" (Workman 1986), i.e., those considered necessary even though they are not economically feasible. As an example, suppose there is a highly visible public range "sore spot" in the form of a steep area that has become denuded of vegetation and highly eroded by indiscriminate offroad vehicle use. Even though it is agreed that the monetary returns from revegtating the area will be far less than the costs, it is also agreed by the land management agency (and the public observing its actions) that the area must be reclaimed. Even in this example, where few people would argue that revegetation was unnecessary, public monies are to be used to fund the project and the agency is obligated to seek a "least-cost" method of revegetation. What began as a biological problem has become an economics-based decision.

Range revegetation efforts are also sometimes made in response to legal requirements that the land be reclaimed. Thus no decision is required concerning whether or not revegetation will be done. However, economic analysis is still a crucial part of the decision of how to accomplish the revegetation goal. Whether public land to be revegetated with public funds or private land to be reclaimed through private investment, the problem is simply to find the least expensive means of achieving the desired revegetation. Instead of searching for the "biggest bang for the buck" as described above, cost effectiveness analysis ${ }^{2}$ tries to produce "a specified bang for the smallest buck" (Workman 1984). While crucial, the required economic analysis for the cost effectiveness case might be quite short. In its simplest form such an "analysis" might consist of only a statement that several proven methods are available to achieve the required revegetation and that the least expensive of these will be used.

\footnotetext{
Note that NPV here, like NPV in Economic Feasibility above, is calculated as the difference between returns and costs, both discounted at the borrowing rate. If discounting is done, instead, at the opportunity cost rate (the rate of return on the best alternative use of capital), then the resulting one project that yields a positive NPV is the economically efficient project.

${ }^{2}$ The term cost effectiveness analysis is defined here as analysis used to select the minimum cost method of accomplishing a goal that has already been set (Howe 1971). This standard definition should not be confused with the use of the term "cost effective" by U.S. Forest Service (1980) as a synonym for the term "economically efficient" discussed above.
} 


\section{Information Required for Analysis}

Information concerning the following items is required for economic analysis of range revegetation: (1) project costs, (2) project benefits, (3) value of benefits, (4) interest rate, (5) project risk, (6) expected project life, and (7) the range site selected for revegetation. Each of these factors influences economic feasibility and efficiency.

\section{Project Costs}

Expected costs of range revegetation include both initial project investment and induced operating and maintenance costs. The main revegetation costs often consist of the initial investment in soil preparation, seed, and seeding. However, when revegetation is done primarily to enhance livestock forage production and allow breeding herd expansion, the induced costs of increasing the herd (whether purchased or retained from homegrown young stock) may exceed the initial costs of revegetation, itself (Workman 1986). Other important revegetation induced costs include construction and maintenance of fences and stock water facilities required to control grazing on reclaimed areas. These induced costs can be an important determinant of the economic success of revegetation efforts. Kearl and Brannan (1967) found, for example, that differences in fencing requirements for vegetation conversion projects can cause a $300 \%$ variation in per hectare treatment costs on small tracts of land. The crucial influence of grazing deferment cost on the economic feasibility of revegetation is examined in detail below. In the range reseeding example to follow (Table 1) initial investment consists of $6.7 \mathrm{~kg} / \mathrm{ha}$ of Fairway crested wheatgrass (Agropyron cristatum (L.) Gaertn.) seed at $\$ 2.67 / \mathrm{kg}$ and plowing and seeding costs of $\$ 39.54 / \mathrm{ha}$, a total initial investment of $\$ 57.43 /$ ha (USDA 1984).

\section{Project Benefits}

Some revegetation projects primarily yield stable soils and watersheds and their most important benefits might best be measured in terms of decreased erosion and improved water quality. But often the most important quantifiable impacts of reclamation efforts are increases in quantity and quality of livestock forage. The forage benefits lead to (1) increased yearlong carrying capacity, allowing herd expansion, and (2) reduced per animal feed costs since range forage can be substituted for more expensive harvested or purchased feeds.

Suppose the area to be revegetated is rangeland classified as the Upland Loam range site and is currently in poor condition. Current herbage production is $1,318 \mathrm{~kg} / \mathrm{ha}(1,176 \mathrm{lb} / \mathrm{ac})$, the average of $715 \mathrm{~kg} / \mathrm{ha}(638 \mathrm{lb} / \mathrm{ac})$ and $1,921 \mathrm{~kg} / \mathrm{ha}(1,714 \mathrm{lb} / \mathrm{ac})$ reported by Mason (1971) for poor condition (Fig. 1). Suppose further that seeding the area to an introduced cool-season grass such as crested wheatgrass will increase herbage production to $1,511 \mathrm{~kg} / \mathrm{ha}(1,348$ $\mathrm{lb} / \mathrm{ac})$, the average of $1,009 \mathrm{~kg} / \mathrm{ha}(900 \mathrm{lb} / \mathrm{ac})$ and $2,013 \mathrm{~kg} / \mathrm{ha}$ $(1,796 \mathrm{lb} / \mathrm{ac})$ for good condition (Fig. 1). In poor condition, only $23 \%$ of the total plants on this site are forage species (Fig. 1). If forage utilization is $50 \%, 152 \mathrm{~kg} /$ ha of usable forage are produced annually (Table 1). If the animal unit month (AUM) requirement is $300 \mathrm{~kg}$ (National Research Council 1970), this site in poor condition has a carrying capacity of $0.51 \mathrm{AUM} /$ ha. If the seeded stand results in $90 \%$ forage species, the carrying capacity is 2.27 $\mathrm{AUM} / \mathrm{ha}$, a $1.76 \mathrm{AUM} / \mathrm{ha}$ increase over that before seeding (Table 1).

\section{Value of Benefits}

The next step in the economic analysis of our reseeding example is to assign a value to increased carrying capacity. Several analytical techniques have been used to estimate the dollar value of increased forage. These techniques may be grouped into 2 categories: (1) complex approaches that estimate the value of increased livestock production made possible by additional AUMs and (2) simple approaches that value additional AUMs of forage in terms of lease price.

\section{Value as Increased Livestock Production}

Valuing revegetation benefits in terms of increased livestock production requires tracing the impacts of increased seasonal forage (spring-fall carrying capacity in our reseeding example) on yearlong forage balance and the resulting increase in yearlong breeding herd carrying capacity (Workman and MacPherson 1973). It also involves the use of "partial budgeting" to determine the resulting added annual livestock returns, added annual livestock operating costs, and added initial investment, including increasing the size of the breeding herd (Workman 1986, Cook and Stubbendieck 1986, and Scifres 1987). Budgeting is a simple procedure to estimate the effects of production changes on costs and returns (Caton 1957). In partial budgeting, the costs and returns that are not affected (taxes, insurance, depreciation) by proposed management changes are omitted from the calculations (Cook and Stubbendieck 1986).

This process of valuing increased forage production has become much easier and faster as partial budgeting "by hand" has been replaced by spreadsheets, linear programming (LP), and other optimization techniques applicable to range improvement decisions. While noncomputer-assisted partial budgeting can deal with only 1 proposed improvement at a time, LP can calculate the optimum combination of potential range improvement practices (Jameson et al. 1974). Kim (1971), Beneke and Winterboer (1973),

Table 1. Comparison of per hectare costs, increased production, increased annual return, and net present value (20-year life, $9 \%$ interest) due to seeding 2 range sites.

\begin{tabular}{|c|c|c|c|c|c|c|c|c|c|c|c|}
\hline \multicolumn{12}{|c|}{ Upland Loam Range Site } \\
\hline & $\begin{array}{c}\text { Herbage } \\
(\mathrm{Kg} / \mathrm{Ha} / \\
\mathrm{Yr}) \times\end{array}$ & $\begin{array}{c}\% \\
\text { Forage } \times\end{array}$ & $\begin{array}{c}\% \\
\text { Utiliza- } \\
\text { tion }\end{array}$ & $=\begin{array}{c}\begin{array}{c}\text { Forage } \\
(\mathbf{K g} / \mathbf{H a} /\end{array} \\
\left.\mathrm{Yr}_{\mathbf{r}}\right)\end{array}$ & $\begin{array}{c}\text { Req. } \\
\text { forage } \\
\text { (Kg/ } \\
\text { AUM) }\end{array}$ & $\begin{array}{c}\text { Car. } \\
\text { cap. } \\
(\mathrm{AUM} / \\
=\quad \mathrm{Ha})\end{array}$ & $\begin{array}{c}\text { Incr. } \\
\text { prod. } \\
\text { (AUM/ } \\
\text { Ha) }\end{array}$ & $\begin{array}{c}\text { Ann } \\
\text { value } \\
\text { incr. } \\
\text { prod. } \\
(\$ / \mathrm{Ha})\end{array}$ & $\begin{array}{c}\text { PV } \\
\text { incr. } \\
\text { prod. } \\
(\$ / \mathrm{Ha})\end{array}$ & $\begin{array}{l}\text { Init. } \\
\text { inv. } \\
(\mathbf{S} / \mathrm{Ha})\end{array}$ & $\begin{array}{c}\text { NPV } \\
(\$ / H a)\end{array}$ \\
\hline After seeding & 1511 & 90 & 50 & 680 & 300 & 2.27 & & & & & \\
\hline Before seeding & 1318 & 23 & 50 & 152 & 300 & .51 & 1.76 & 14.94 & 136.37 & 57.43 & 78.94 \\
\hline \multicolumn{12}{|c|}{ Upland Shallow Loam Range Site } \\
\hline After seeding & 1288 & 90 & 50 & 580 & 300 & 1.93 & & & & & \\
\hline Before seeding & 599 & 27 & 50 & 81 & 300 & .27 & 1.66 & 14.09 & 128.62 & 57.43 & 71.19 \\
\hline
\end{tabular}




\section{YIELD AND VEGETATION COMPOSITION Upland Loam Range Site}
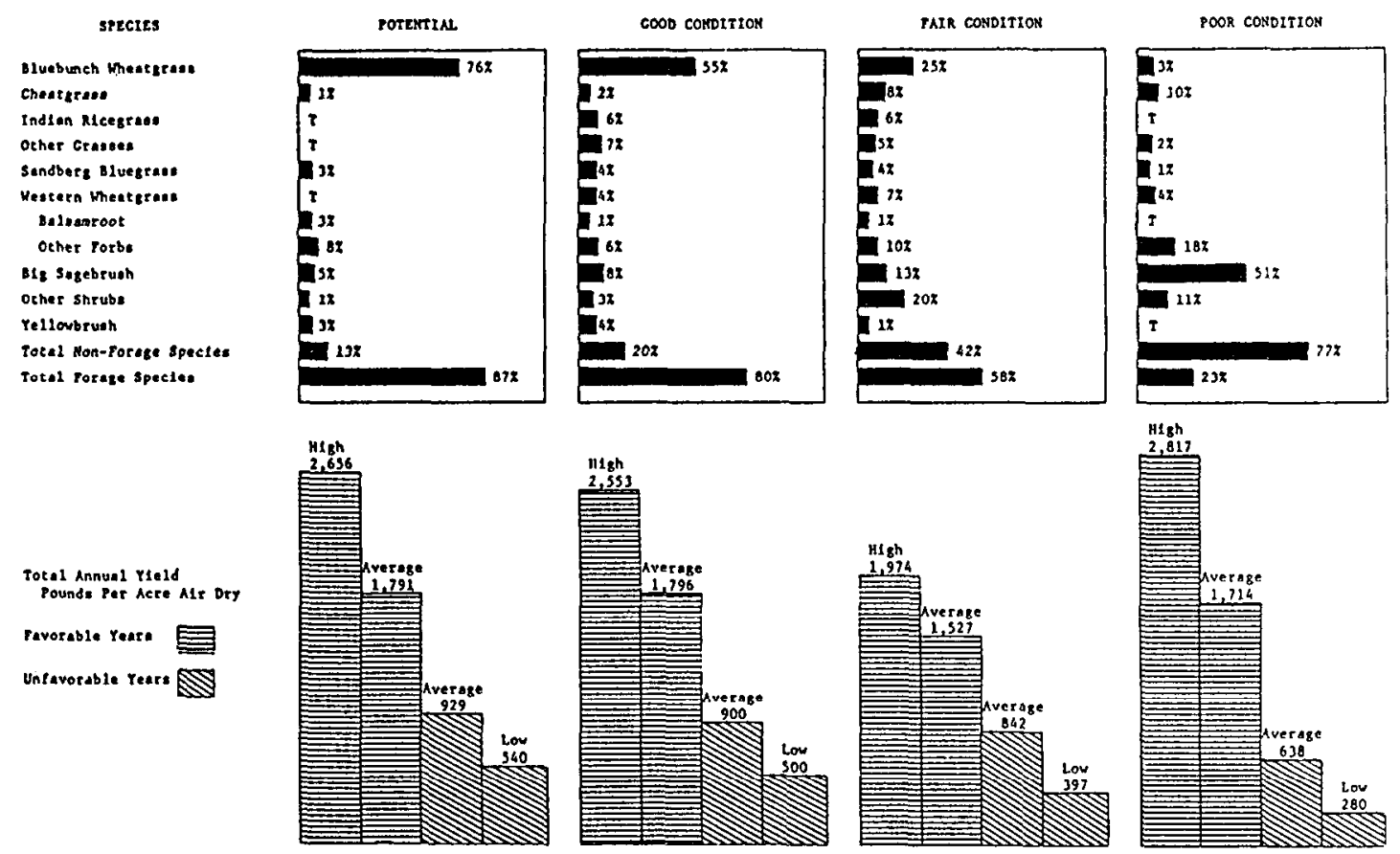

Fig. 1. Yield and composition, Upland Loam range site (from Mason, 1971).

and Jameson et al. (1974) provide detailed discussions of the mathematics involved. Examples of LP applications to range vegetation conversion or revegctation decisions include Sharp and Boykin (1967), Child and Evans (1976), and Tanaka and Workman (1988).

It is sometimes comforting to range professionals who haven't studied economics to be reminded that LP is based on traditional procedures of partial budgeting (Workman 1986). The computer only makes the process faster and easier and allows numerous production constraints (i.e., seasonal forage, labor, borrowed capital) to be analyzed simultaneously.

Space does not allow a demonstration of valuing revegetation benefits in terms of increased livestock production. Several detailed examples of this procedure are available in the literature (Workman 1986, Cook and Stubbendieck 1986, Tanaka et al. 1987, Vallentine 1989).

\section{Value as Leased Forage}

Valuing revegetation benefits as privately leased forage is simple and straightforward. In many cases this approach yields accurate estimates of the value of increased forage from revegetation, particularly in situations where the land owner currently leases forage from other rangeland owners and can avoid paying future lease fees by revegetating his/her own rangeland (Workman 1986). Even a land owner not currently involved in leasing usually has the opportunity to lease increased private forage to neighboring operators so pricing increased forage production at the private lease rate is valid.

It should be noted that pricing at the private lease rate often yields a higher revegetation benefit than does valuation as increased livestock production (Workman 1986). It should also be noted that published private lease rates include a premium for landlord services of about 30\% (Torell et al. 1989a) and that the value of additional forage, itself, is only about $70 \%$ of published lease rates. However, for simplicity in the following reseeding example, increased forage will be valued at $\$ 8.49 \mathrm{per}$ AUM. This is the average private lease rate for the 16 western states, 1985-87 (USDA 1988).

\section{Interest Rate}

\section{Real Versus Nominal Interest Rates}

Calculation of NPV of our reseeding project requires that all future costs and benefits be discounted to the present. Care must be taken to express all prices and interest rates in consistent terms, either all real or all nominal (Howe 1971, Overton and Hunt 1974, Hanke et al. 1975). In economics parlance, a real price is one that is inflation-free while a nominal price includes inflation.

The above $\$ 8.49$ per AUM value is a real price. It is projected into the future, over the entire life of our reseeding, in constant 1987 dollars. For consistency, since inflation is not included in future benefits, neither should it be included in the discount rate. So this real future flow of revegetation benefits must be discounted at a real interest rate. Borrowing rates charged by lending institutions are expressed in nominal terms. A $10 \%$ rate quoted by a bank for a reseeding loan is the sum of the bank's required real rate of return, say, $4 \%$ and an expected inflation rate of $6 \%$. A real borrowing rate, then, is calculated by subtracting the expected inflation rate from the quoted nominal borrowing rate.

Alternatively, both revegetation benefits and the discount rate could be expressed in nominal terms. This would involve combining the known (quoted) nominal borrowing rate $(10 \%$ in our example) with predicted future nominal forage prices over the life of the reseeding project. Due to the tendency for fluctuating live- 


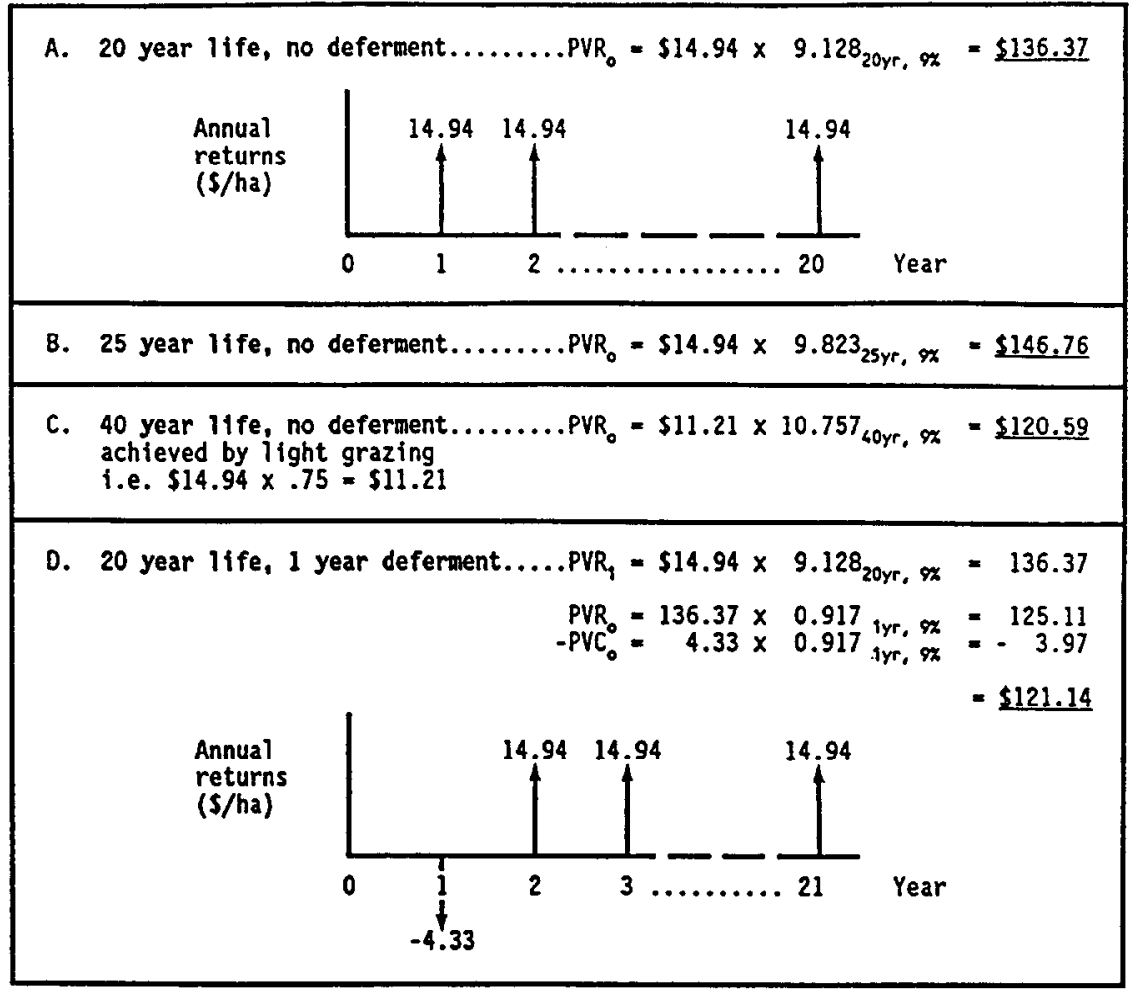

Fig. 2. Effects of extending the useful life and of requiring a 1-year grazing deferment on the present value of annual returns to range revegetation.

stock prices not to keep pace with general inflation trends, some researchers believe that projecting current livestock prices over project life yields a measure of nominal project benefits (Ethridge et al. 1987). Both the nominal and the real approaches are correct, provided that they are kept consistent. For analysis of our reseeding example, we will combine the real forage price of $\$ 8.49$ per AUM (USDA 1988) with a risk-free real discount rate of $4 \%$ (Row et al. 1981).

\section{Risk}

Many range revegetation projects involve some degree of risk. Numerous factors can cause actual results to deviate from those expected. Due to variability in weather and price alone, results can seldom be predicted with complete certainty (Cook and Stubbendieck 1986).

In everyday usage, "risk" describes any departure of actual from expected results. For economic analysis, however, risk should be further divided into "risk" and "uncertainty" (Cook and Stubbendieck 1986). The probabilities of occurrence of some events (e.g., a severe drought) can be calculated, based on records of the past. This is true "risk". The probabilities of other events (e.g., livestock prices in a freely fluctuating market) cannot be calculated. This is "uncertainty". Various attempts to deal with the risk and uncertainty of range management and range improvements are detailed in the literature (Whitson 1975, Banner 1981, Whitson et al. 1982, and Walker and Helmers 1983).

Economic analysis of range revegetation or vegetation conversion must include risk since the probability of biological success or failure can affect economic results as much as any factor considered here (Tanaka and Workman 1989). It is much easier, of course, to incorporate risk than uncertainty. We will deal only with risk in our reseeding example.

Suppose that based on past reseeding records for the Upland Loam site we calculate the risk of seeding failure to be one failure out of 20 seedings (5\%). In the literature, such risk has been incorporated into the analysis in 2 ways. First, risk can be included by adding a risk premium to initial investment (Row et al. 1981) and then discounting real returns and costs using a risk-free discount rate. In our example, this would require adding $5 \%$ to our $\$ 57.43 /$ ha initial investment, resulting in a risk-included initial investment of $\$ 60.30 /$ ha. Or, second, real returns and costs can be discounted using a risk-included discount rate (Arrow and Lind 1970, Howe 1971) and no risk premium added to initial investment. In our example, this would require adding the $5 \%$ risk rate to the $4 \%$ real borrowing rate to give a real risk-included discount rate of 9\%. We will analyze our reseeding example using this second approach.

\section{Project Life}

Migration of less desirable vegetation into a seeded or converted area is usually a gradual but almost inevitable process. While revegetation benefits do not end abruptly, a time may come when forage production and livestock carrying capacity return to their pre-treatment rates. While estimates of benefit duration are subjective, at best, such estimates must be made in economic evaluation of revegetation and should be based on research results and management experience on the range site to be treated (Workman 1986). The dynamic impacts of this process are discussed in the optimal vegetation conversion and use section below.

\section{Life Extension}

Traditionally, range managers have been conservative in estimating expected project life. It is common to view a 30-year-old range seeding where the drill rows are still plainly visible and to learn that at the time of establishment its useful life was projected to be 20 years. But these conservative projections by range professionals do not do violent damage to the accuracy of economic analysis. Suppose that we projected a 20 -year life (Fig. 2A) for the Upland Loam seeding of Table 1 but the actual life was 25 years 
(Fig. 2B). This 5-year under-estimate reduces present value of annual returns $\left(\mathrm{PVR}_{0}\right)$ by only $\$ 10 /$ ha (from $\$ 146.76 /$ ha to $\$ 136.37)$. It is comforting to note that under-estimating project life results in a proportionately smaller under-estimate of $\mathbf{P V R}_{0}$. Much less comforting is the fact that extending the life of an already long-lived project is also not worth much in present dollars. A 5 -year $(25 \%$ ) life extension (from 20 to 25 years) adds only $\$ 10$ (8\%) to PVR. Of course, if the seeding life could be extended 5 years at no cost, that would be great. But project life extension is not free. Suppose seeding life could be doubled from 20 to 40 years if annual grazing use were reduced $25 \%$. How would this affect the economic outcome of the project? Doubling project life in this case actually reduces $\mathrm{PVR}_{\mathrm{o}}$ by about $\$ 15 /$ ha (from $\$ 136.37 /$ ha in Fig. $2 \mathrm{~A}$ to $\$ 120.59 /$ ha in Fig. 2C). The important conclusion is that extending an already long-lived project is not worth much in discounted dollars.

\section{Grazing Deferment}

Since adding distant-future years to expected life is worth so little in discounted dollars, perhaps it is not surprising that subtracting near-present years from expected life is very costly to economic feasibility. This is best demonstrated by requiring a grazing deferment for our reseeding example. Deferments were not required for the seedings portrayed in Fig. 2A, 2B, and 2C. These cases are based on seeding in the fall after normal spring-fall grazing is completed and then returning to graze the following fall after the seeding has completed 1 full growing season. Now suppose that we require complete grazing deferment during the entire year after seeding. Deferment brings 2 changes to the "flow" of reseeding benefits over time (Fig. 2D). First the initiation of production response is postponed from year 1 to year 2. This 1-year change reduces $P V R_{0}$ by $\$ 11 /$ ha (from $\$ 136.37 /$ ha to $\$ 125.11$ ). Second, an alternative forage source must be found to replace the pre-treatment carrying capacity not available during year 1 (Nielsen 1984). The value of this alternate forage is $0.51 \mathrm{AUM} / \mathrm{ha}$ (from Table 1) $\times \$ 8.49 / \mathrm{AUM}=\$ 4.33 /$ ha and must be treated as a cost in year 1 . This alternate forage must come from either owned land (in which case the opportunity to devote this forage to other uses is forgone) or must be leased from a neighboring landowner at the going private rate. In present dollars, this alternate forage costs $\$ 3.97 /$ ha seeded (Fig. 2D). Combined, the 2 changes due to grazing deferment reduce $P V R_{0}$ by $\$ 15 /$ ha or $11 \%$ (from $\$ 136.37 /$ ha to \$121.14).

Imposing a year of grazing deferment brings a substantial reduction in revegetation PVR $_{0}$. Is there anything positive that can be said about required deferment of reseeded areas? Happily, yes, and it's simply this: there is probably no greater contribution that a range professional could make towards improving economic feasibility of revegetation than to develop ways to ensure revegetation success with less required deferment.

\section{Range Site Selected for Revegetation}

In almost any range revegetation or vegetation conversion decision, the amount of land that would respond to treatment far exceeds the amount that can be treated with the available budget. So the range manager must often first decide how much of which range site(s) to revegetate. Range managers have sometimes tended to concentrate their limited improvement budgets on the worst sites (the most fragile and least productive and responsive) because "these worst sites need improvement more" than the best sites (those most resilient, productive, and responsive). Unfortunately, this "worst first" thinking confuses what we might like to do with what we can afford and can cause serious errors in allocating revegetation budgets between sites. Instead, if our goal is to maximize response (revegetation success, increased forage, and increased

\section{YIELD AND VEGETATION COMPOSITION Upland Shallow Loam Range Site}

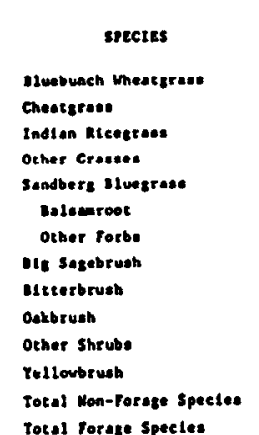

Tocel rorage Spectes
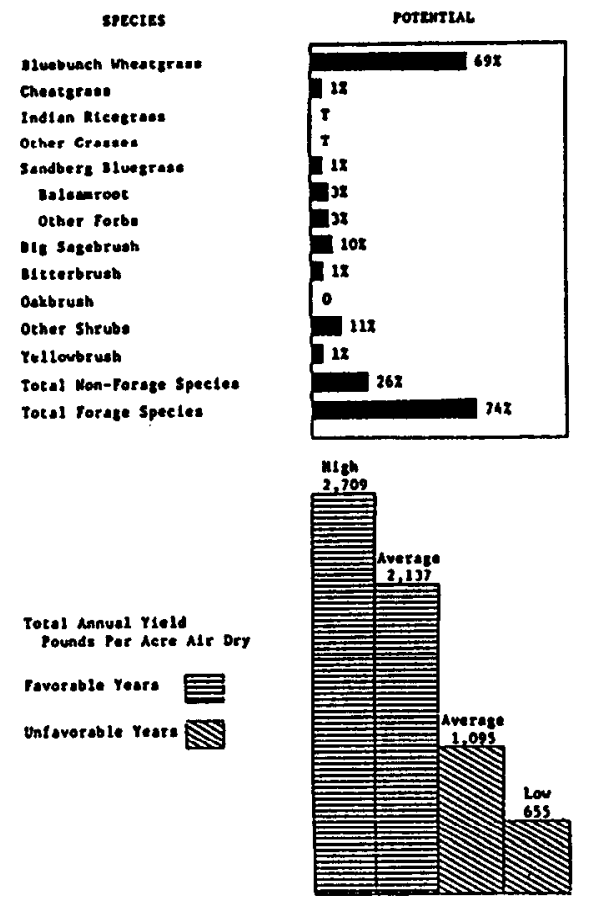
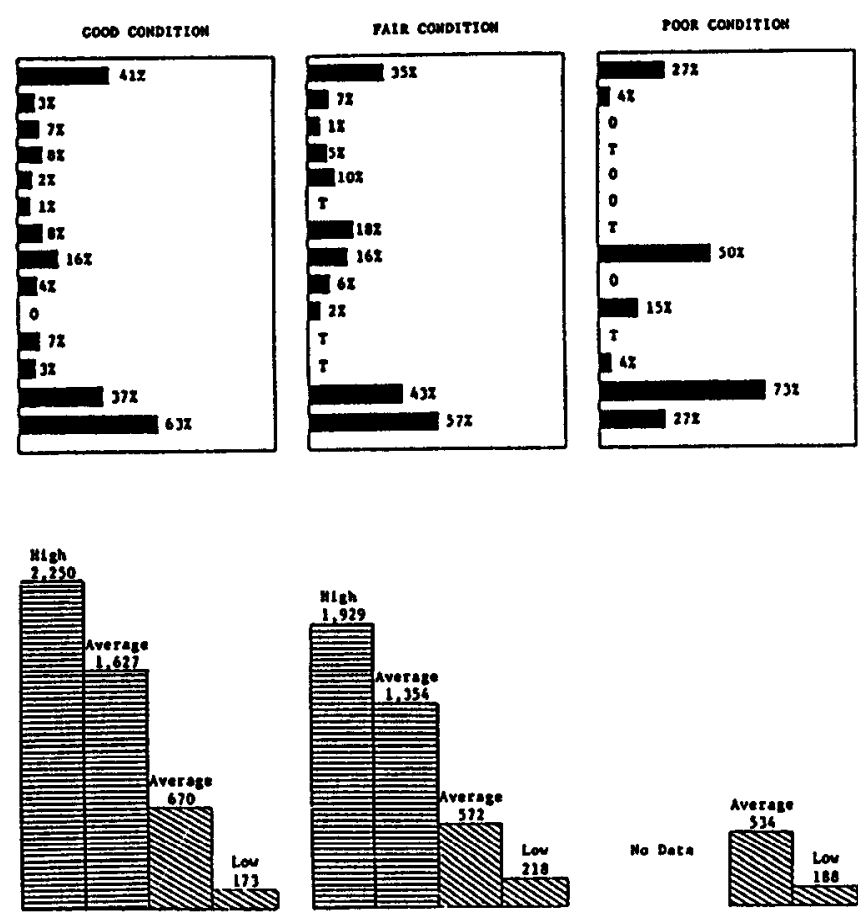

Fig. 3. Yield and composition, Upland Shallow Loam range site (from Mason, 1971). 
annual returns) to limited revegetation budgets, time, and other resources, we should treat our best sites first (Workman 1986). We will use the information in Figures 1 and 3 and Table 1 to demonstrate this important rule.

Nielsen and Hinckley (1975) observed that there is often a direct relationship on a particular rangeland area between pretreatment and posttreatment forage production. This relationship is apparent in Table 1 for our reseeding example. In poor condition (before seeding), forage production of the Upland Shallow Loam site is less than on the Upland Loam (Fig. 3 compared to Fig. 1). The Upland Shallow Loam site is also less responsive to reseeding. The same reseeding treatment (Table 1), with the same initial investment of $\$ 57.43 /$ ha produces a larger forage production increase on the Upland Loam than Upland Shallow Loam (1.76 AUM/ha versus $1.66 \mathrm{AUM} / \mathrm{ha}$ ). While this $0.1 \mathrm{AUM} /$ ha difference might appear small, the resulting $\$ 8 /$ ha difference ( $\$ 78.94$ vs. $\$ 71.19$ ) in Net Present Value (NPV $=$ PVR $_{0}$ - Initial Investment) is not.

Reseedings on both sites are economically feasible since both

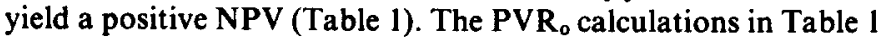
(and Fig. 2) are based on the borrowing rate. As mentioned above, ideally the discount rate should be the higher of either the borrowing or the opportunity cost rates. However, because the opportunity cost (in this case the rate of return on the best alternative use of capital required for the reseeding) is not always known, economic analysis of range improvements is often based on the borrowing rate (Workman 1986). If the only alternative use of funds required to reseed the Upland Loam site were to reseed the Upland Shallow Loam site, we can conclude that, in addition to being economically feasible, our Upland Loam seeding is economically efficient (it yields the highest possible NPV). We can conclude that our Upland Shallow Loam seeding, while economically feasible, is not economically efficient since we know of at least 1 other use of the required funds that will yield a higher NPV (seeding the Upland Loam).

\section{Optimal Vegetation Conversion and Use}

Consistent with the economic efficiency goal discussed above, vegetation conversion must be implemented at a level that will maximize net returns (however measured). In order for this to occur in a long-run dynamic setting, there are 3 important vegetation conversion variables that must be included in the analysis. These are the long-term response function, project life, and expected use of the treated area.

The ranch or grazing allotment forms the analytical basis for economic analysis of vegetation conversion. If vegetation conversion is intended to reverse declining range condition (desertification) on private (or public) land and the rancher (or public land manager) has the goal of maximizing net returns (or net benefits to society) from limited investment funds, we need to answer 4 questions: (1) What percentage of the undesirable vegetation should be targeted for removal? (2) How many hectares should be treated? (3) What should be the grazing intensity on the treated area? and (4) How often should the area be retreated (i.e., what is the optimal project life)?

Numerous analytical methods have been used to determine economically optimal vegetation conversion practices. These have varied from relatively simple static methods to decidedly more complex dynamic methods (Dykstra 1984). No matter what method is used, the same information is required but is used differently. The most important variable is the long-term response function. In the static case, an average treatment response is assumed over the life of the project, holding all else constant. In the dynamic case, response changes over time as a function of initial treatment level, grazing intensity, and random effects (e.g., weather).

The simplest method (and probably the one that has been used the longest) is linear programming (LP). Even though LP can optimize management inputs for maximum net returns, it cannot adequately address the above questions. This has led to the use of increasingly complex models in problem formulation. Bernardo and Conner (1989) have discussed the advantages and disadvantages of applying several more complex methods (e.g., dynamic programming, optimal control theory, expert systems) in range economics. However, in most instances we do not have enough information on long-term response functions to reliably use these methods so we are left with 3 compromises: (1) do nothing while waiting for more data, (2) make educated guesses about the response function, or (3) rely on simpler methods and attempt near-optimal solutions while recognizing the inherent limitations of these methods.

The literature reveals some general "rules" that apply to revegetation and subsequent management from an economic perspective. First, the more complete the removal of an undesirable overstory species, the greater the initial investment cost, understory species response, and project life. Studies on many U.S. vegetation types have shown a convex relationship between understory production and overstory reduction percentage (Tanaka 1986). Second, the heavier the grazing intensity on a revegetated stand, the shorter its life but the greater the NPV. As explained above, this is due to the fact that returns received early in the project life have a much higher present value than returns received far into the future. Third, the number of hectares treated must be balanced with the expected vegetation response and the value of additional forage during the season of the year when available for grazing. In order to optimize vegetation conversion inputs for maximum net returns, all of these "rules" must be balanced together.

The theoretical basis for optimal overstory reduction on big sagebrush (Artemisia tridentata Nutt.) sites revegetated with crested wheatgrass (Agropyron cristatum (L.) Gaertn., A. desertorum (Fisch. ex Link) Schult.) has been examined by Torell (1984) and Tanaka (1986). Case studies applying the theoretical model have also been developed (Tanaka and Workman 1988, 1990; Torell and McDaniel 1986; Torell and Hart 1988; Torell et al. 1989 b, c). The interactions among decision "rules" described above were evident in the reported results. For example, if grazing intensity of crested wheatgrass was held constant, optimal (maximum NPV) big sagebrush reduction was 92 to $100 \%$ for a specified project life (Tanaka and Workman 1988). If grazing intensity was increased, however, project life would be shortened (Torell 1984). The overall goal is to find the balance of the 3 factors (initial reduction percentage, grazing intensity, and project life) that will lead to maximum NPV over an infinite time horizon.

Continuing with the seeding example, we will expand the analysis to consider the dynamic aspects of the problem. A dynamic production function is affected by both the amount of initial overstory removal and subsequent utilization rate (Fig. 4). The value of the forage produced, cost of the vegetation conversion, and interest rate remain the same. In the dynamic case each year's benefits must be discounted individually. Adding these values together over the life of the project results in PVR $_{0}$ as before.

The static and 3 dynamic cases are illustrated in Figure 4 . The first dynamic case (D-50-95) assumes a $50 \%$ utilization rate and $95 \%$ initial overstory removal. This results in a 20 -year project life due to big sagebrush encroachment into the stand. If we decide to stock heavier and achieve a $75 \%$ utilization, we will obtain more forage in early years of the project but there will be a project life of only 15 years (D-75-95). If the goal of the conversion project were to leave half the sagebrush for other resource uses and stock at $50 \%$ utilization (D-50-50), we expect more than $50 \%$ reduction in usable forage due to the convex shape of the projection function and a more rapid stand deterioration (i.e. project life of only 10 years). 
Kim, C. 1971. Introduction to linear programming. Holt, Rinehart, and Winston, Inc., N.Y.

Martin, W.E. 1972. More sophisticated tools for less important problems The history of range improvement research: A comment. Amer. J. Agr. Econ. 54:134-135.

Mason, R. 1971. Yield and composition of Utah's range sites. USDA-SCS. Portland, Ore.

National Research Council. 1970. Nutrient requirements of beef cattle No. 4. Beef Cattle. 4th rev. ed. Washington, D.C.

Nielsen, D.B. 1984. Economic factors to be considered in sagebrush/grassland management. p. 1373-1386. In: Developing strategies for rangeland management. Nat. Res. Counc./Nat. Acad. of Sci. Westview Press, Boulder, Colo.

Nielsen, D.B., and S.D. Hinckley. 1975. Economic and environmental impacts of sagebrush control on Utah's rangelands. Utah Agr. Exp. Sta. Res. Rep. 25.

Overton, W.S., and L.M. Hunt. 1974. A view of current forest policy, with questions regarding the future state of forests and criteria of management. Trans. 39th N. Amer. Wildl. and Natur. Res. Conf. Wildl. Manage., Inst. Washington, D.C.

Row, C., H.F. Kaiser, and J. Sessions. 1981. Discount rate for long-term Forest Service investments. J. Forest. 79:367-376.

Scifres, C.J. 1987. Decision-analysis approach to brush management planning: Ramifications for integrated range resources management. J. Range Manage. 40:482-480.

Sharp, W.W., and C.C. Boykin. 1967. A dynamic programming model for evaluating investments in mesquite control and alternative cattle systems. Tech. Monogr. 4. Texas Agr. Exp. Sta., College Station.

Tanaka, J.A. 1986. Economic optimum overstory reduction for increasing seasonal forage production. Ph.D. Diss. Utah State Univ., Logan.

Tanaka, J.A., and J.P. Workman. 1988. Economic optimum big sagebrush control for increasing crested wheatgrass production. J. Range Manage. 41:172-178.

Tanaka, J.A., and J.P. Workman. 1990. Optimal vegetation conversionhow much, how often? Rangelands 12:33-36.

Tanaka, J.A., L.A. Torell, and J.P. Workman. 1987. FEEdSTOR IS: a micro-computer program for ranch planning. Rangelands 9:51-55.

Torell, L.A. 1984. Economic optimum stocking rates and treatment schedule for crested wheatgrass stands. Ph.D. Diss. Utah State Univ., Logan.

Torell, L.A., and R.H. Hart. 1988. Economic consideration for efficient stocking rates on rangeland, p. 71-76. In: Achieving efficient use of rangeland resources. R.S. White and R.E. Short (eds.). Miles City, Mont., Sept., 1987.
Torell, L.A., and K.C. McDaniel. 1986. Optimal timing of investments to control honey mesquite. J. Range Manage. 39:378-382.

Torell, L.A., S. Ghosh, and J.M. Fowler. 1989a. Economic considerations for setting grazing fees on New Mexico state trust lands. New Mexico Agr. Exp. Sta. Spec. Rep. 81.

Torell, L.A., W.W. Riggs, and R.H. Hart. 1989b. Economic principles for efficient grazing use of rangeland with intertemporal considerations. Symp. Proc., Western Regional Coordinating Comm. on Range Econ. WR CC-55, Billings, Mont., Feb. 21, 1989.

Torell, L.A., W.W. Riggs, E.B. Godfrey, and K.S. Lyon. 1989c. Grazing impacts to forage production and the rangeland stocking rate decision, $\mathbf{p}$. 688-697. In: Papers of the 1989 Annual Meeting, Western Agr. Econ. Assoc., Coeur d'Alene, Idaho, July 9-12, 1989.

U.S. Department of Agriculture. 1984. Utah technical guide-Section V-A 1984 average Utah costs: flat rate schedule-conservation practices. SCS, February, 1984. p. 12.

U.S. Dengrtment of Agriculture. 1988. Agricultural resources: Agricultura! land values and markets: situation and outlook. Econ. Res. Serv. AR-10, June, 1988. p. 18.

U.S. Forest Service. 1980. Economic analysis of allotment plans and range improvements. Forest Serv. Handb. 2209.11. Review Draft. Washington, D.C.

Vallentine, J.F. 1989. Range development and improvements, 3rd Edition. Academic Press, New York.

Walker, O.L., and G.A. Helmers. 1983. Risk and risk management in range use. Proc. 56th Annual Meeting of Western Agr. Econ. Assoc., Laramie, Wyo.

Whitson, R.E. 1975. Ranch decision-making under uncertainty-an illustration. J. Range Manage. 28:267-270.

Whitson, R.E., R.K. Heitschmidt, M.M. Kothmann, and G.K. Landgren. 1982. The impact of grazing systems on the magnitude and stability of ranch income in the rolling plains of Texas. J. Range Manage. 35:526-532.

Workman, J.P. 1984. Criteria for investment feasibility and selection. p. 1475-1507. In: Developing strategies for rangeland management. Nat. Res Counc/Nat Acad of Sci. Westview Press, Boulder, Colo.

Workman, J.P. 1986. Range economics. Macmillan Publ. Co., N.Y.

Workman, J.P., and D.W. MacPherson. 1973. Calculating yearlong carrying capacity-an algebraic approach. J. Range Manage. 26:224-227. 